\title{
Congratulatory address of the Fachbereich Biologie der Universität Hamburg
}

\author{
Der Sprecher Professor Dr. L. Kies \\ Institut für Allgemeine Botanik der Universität Hamburg; Ohnhorststraße 18, \\ D-22609 Hamburg, Germany
}

On behalf of the Faculty of Biology, University of Hamburg, I wish to congratulate the Biologische Anstalt Helgoland on the occasion of its 100th anniversary. May the BAH flourish and be scientifically successful for a further term of 100 years.

Over many years, there has been close cooperation between members of the Biologische Anstalt Helgoland and the Faculty of Biology, University of Hamburg. This cooperation will become even closer in the future, in fulfilment of our 1986 Treaty of Cooperation.

I would like to take this opportunity to thank the Biologische Anstalt Helgoland for hosting so many courses in Marine Zoology, Marine Botany, Hydrobiology and Fishery Science, and Marine Microbiology from our Faculty since 1959, when the Meeresstation was re-opened.

In addition to this, numerous graduate students and $\mathrm{PhD}$ students from our Faculty have been guests of the Meeresstation during work on their theses. They all acknowledge the great support given to them by members of the BAH.

Our Faculty is proud to have several members of the BAH among its Faculty members who cooperate in the scientific education of our students, and in a broad range of research activities. 